\title{
SLC4A3 wt Allele
}

National Cancer Institute

\section{Source}

National Cancer Institute. SLC4A3 wt Allele. NCI Thesaurus. Code C105068.

Human SLC4A3 wild-type allele is located in the vicinity of $2 q 36$ and is approximately 15

$\mathrm{kb}$ in length. This allele, which encodes anion exchange protein 3 , plays a role in

chloride/bicarbonate exchange in cardiac myocytes. 